\title{
Desain dan Analisa Permanen Magnet Motor Sinkron untuk Aplikasi pada Lift
}

\author{
Prian Gagani Chamdareno ${ }^{1}$, Erwin Dermawan ${ }^{2}$, Octafriandi Hendra Masruroh ${ }^{3}$ \\ 1,2,3) Jurusan Teknik Elektro, Universitas Muhammadiyah Jakarta \\ Jl. Cempaka Putih Tengah 27 no 47 Jakarta 10510 \\ e-mail : prian.gagani@ftumj.ac.id
}

\begin{abstract}
ABSTRAK
Dengan hadirnya permanent magnet motor synchronous, dapat meningkatkan effisiensi pada motor dan dapat mengurangi torsi, pembahasan dalam hal ini adalah motor $4 \mathrm{kw}$ yang di rancang dengan menggunakan software ANSYS Maxwell 16 dan di bandingkan dengan motor sinkron gearless yang saat ini ada di pasaran
\end{abstract}

Kata kunci : Desain, analisa, permanen, magnet, motor, sinkron

\section{PENDAHULUAN}

Pada saat ini berkembang pesat pembangunan gedung gedung pencakar langit di berbagai belahan dunia , dan gudung tersebut pasti membutuhkan transportasi vertical / Lift dengan kecepatan tinggi agar dapat memobiliasi dengan cepat dari Lantai atas dan bawah maka dengan itu berkembanglah dan bersaing para produsen Lift untuk menciptakan lift / elevator yang handal dan mudah di operasikan. Inovasi dengan mengunakan sistem gearless. Mesin listrik hamper seluruhnya dipakai untuk menghasilkan listrik dan sangat sedikit proses menghasilkan listrik yang tidak melibatkan mesin yang berputar [1]. Saat ini, mesin listrik tidak dapat tergantikan untuk manusia untuk melakukan rutinitas sehari-hari [2]. Elevator tanpa gigi dengan kecepatan rendah telah menjadi tren perkembangan elevator modern [3]. Motor sinkron magnet permanen banyak dipakai karena efisiensi tinggi, kerapatan daya besar dan pengontrolan sederhana [4]. Motor sinkron magnen permanen berbeda dengan motor dc brushless [5]. Mesin magnet permanen non-menonjol dianggap kandidat yang buruk untuk operasi pelemahan fluks karena karakteristik induktansi rendah yang melekat [6]. Konfigurasi dengan slot-winding fraksional menunjukkan kualitas torka yang lebih rendah [7]. Penggunaan magnet permanen pada konstruksi mesin listrik membawa manfaat seperti tidak adanya energi yang diserap oleh system eksitasi medan [8]. Solusi tradisional untuk system elevator mengimplikasikan sebuah pengurangan gear untuk mencocokkan katrol kecepatan rendah dengan yang lebih tinggi dari sebuah motor listrik konvensional [9]. System elevator pada umumya memiliki sebuah ggi reduksi untuk mencocokkan kecepatan rendah di mana katrol harus berputar dengan kecepatan yang lebih tinggi [10]. Sumber energi fosil seperti minyak bumi, gas alam dan batubara akan bisa bertahan jika sumber energi terbarukan digunakan [11]. Perkembangan dibidang ilmu pengetahuan dan teknologi memiliki kemajuan yang sangat pesat yang berdampak pada kehidupan kita saat ini [12]. Intensitas radiasi cahaya matahari yang diterima sel surya sebanding dengan tegangan dan arus listrik yang dihasilkan oleh sel surya [13]. Perkembangan teknologi mendorong sektor industri untuk lebih kreatif dalam membuat sebuah alat sederhana yang dapat membantu masyarakat dalam kehidupan sehari-hari sehingga dapat berguna bagi banyak orang dan berfungsi baik [14]. Transistor efek medan berbasis semikonduktor organik bisa dimanfaatkan untuk sensor kelembaban [15]. Security home adalah sebuah rumah yang didesain untuk menjaga kemanan rumah melalui perangkat keras maupun perangkat lunak untuk memberikan keamanan dari segi pintu, system alarm, detector gerak (passive infrared), detector api, gas, maupun air [16]. Mengerjakan proyek tepat waktu sesuai dengan biaya, lingkup pekerjaan, serta mutu yang sudah ditetapkan menjadi target setiap perusahaan [17]. Salah satu bahan semikonduktor organik yang sering digunakan adalah pentacene karena ketersediaannya dan kinerja divaisnya [18]. Arduino berfungsi membaca nilai pada sensor tegangan AC, sensor tegangan DC, LCD [19]. Transistor film tipis organik memiliki potensi untuk penggunaan pada aplikasi elektronika yang biayanya rendah, permukaannya luas, ringan dan fleksibel [20]. Untuk dapat mendayai suatu beban listrik dengan baik, dalam hal ini merupakan rumah kaca, diperlukan desain sistem yang baik pula [21]. Energi sangat penting untuk manusia untuk bisa bertahan hidup [22]. Energi listrik merupakan salah satu kebutuhan pokok yang sangat penting dalam kehidupan manusia saat ini, hampir semua aktifitas manusia berhubungan dengan energi listrik [23, p. 6]. Ada banyak sumber energi terbarukan seperti energi air, energi angin dan energi matahari [24]. Rangkaian 
RESISTOR (Elektronika Kendali Telekomunikasi Tenaga Listrik Komputer) Vol. 2 No. 2 e-ISSN : 2621-9700, p-ISSN : 2654-2684

penyearah gelombang penuh adalah penyearah yang mengonversikan kedua siklus positif dan negative dari sinyal AC menjadi sinyal DC yang berdenyut [25]. Rangkaian band pass filter adalah rangkaian yang mengizinkan lewat sinyal yang memiliki frekuensi pada rentang tertentu dan mengattenuasikan sinyal yang memiliki frekuensi di luar rentang tersebut [26]. Didalam sistem jaringan distribusi listrik lokal (local grid) yang kita mengenal istilah microgrid dan nanogrid yang terkenal untuk pembangkit listrik yang berdiri sendiri [27]. Sepeda motor merupakan kendaraan yang lazim digunakan oleh semua kalangan; mulai dari kalangan atas, menengah, sampai kalangan bawah [28]. Pengukuran adalah suatu pembandingan antara suatu besaran dengan besaran lain yang sejenis secara eksperimen dan salah satu besaran dianggap sebagai standar [29]. Penggunaan kapasitor bank di industri misalnya sebagai alat kompensator faktor daya, memperbaiki drop tegangan pada ujung jaringan, atau kenaikan suhu dan arus pada penghantar bisa diperkecil dengan di pasang kapasitor [30]. Tegangan sirkuit terbuka akan bertambah jika sel sel surya dihubungkan secara seri [31]. Operasi pembangkit tenaga listrik harus aman dan terpercaya [32]. Kemajuan teknologi yang pada masa sekarang ini terus mengalami perkembangan dan di ikuti oleh sebagian bahkan hampir semua kalangan [33]. Dihunian yang modern saat ini, tak sedikit pula rumah yang memiliki kamera cctv untuk mendukung keamanan rumahnya [34]. Rumusan masalah adalah bagaimana cara desain permanent magnet motor sinkron dan desain permanen magnet motor sinkron untuk mengurangi flux density dan mengurangi torsi. Batasan masalah desain permanent magnet motor sinkron, spesifikasi motor 380 volt, 159,5 rpm , 4kw, simulasi dilakukan dengan software ANYS Maxwell 16. Tujuan penelitian ini adalah mempelajari cara Desain motor permanent magnet motor sinkron dari desain stator ,winding stator,slos stator , rotor , rotor winding dan cara mengurangi harmonic dan torsi. Dengan penelitian diharapkan mendapat manfaat mengetahui cara desain permanent magnet motor sinkron dan dapat menggunakan software maxwell 2D sebagai bahan simulasi.

\section{METODE}

Metode penelitian yang dilakukan adalah dengan studi literature,simulasi dan pengolahan data

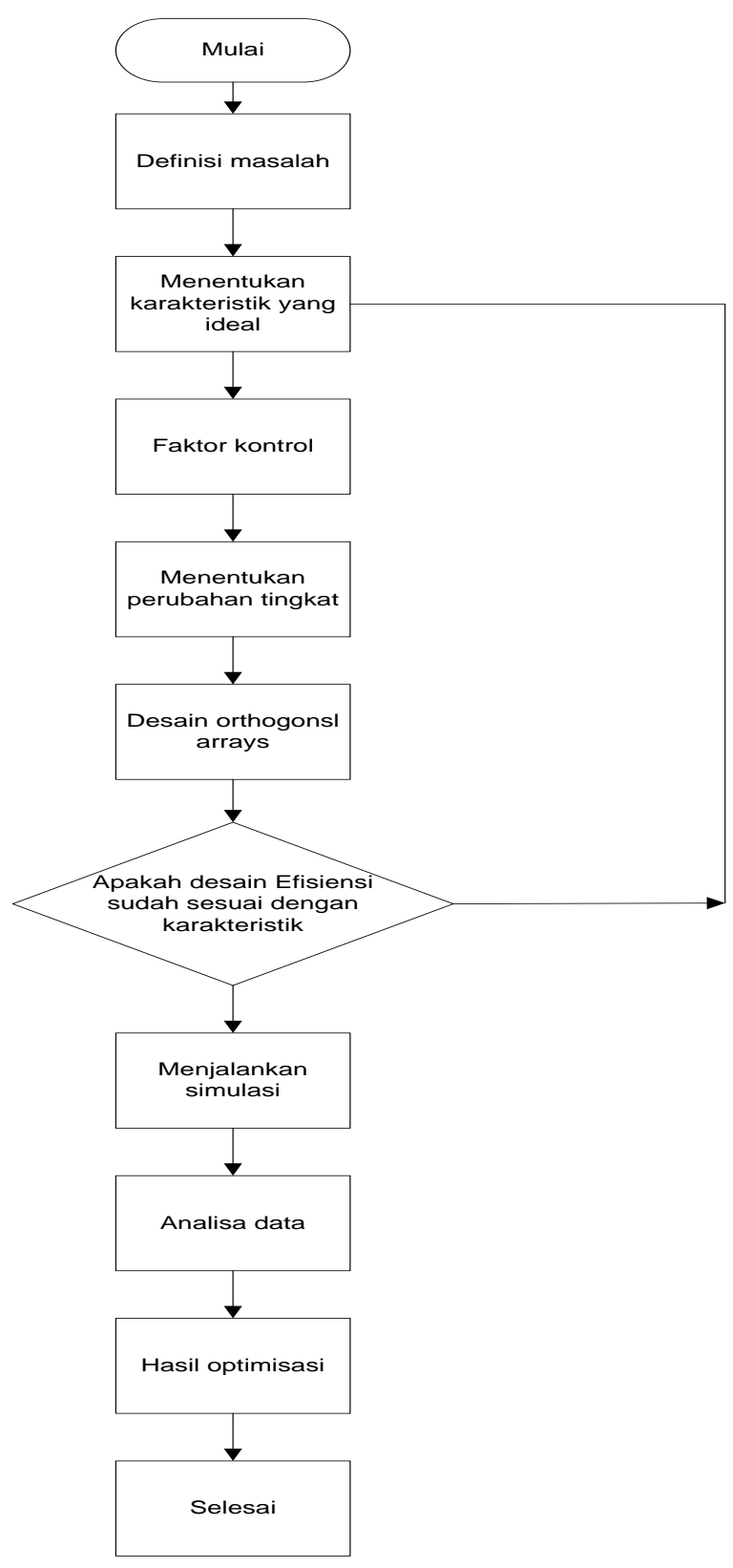

Gambar 1 Diagram alir penelitian.

Tahap perancangan dan simulasi menggunakan Software ANYS Maxwel. 
RESISTOR (Elektronika Kendali Telekomunikasi Tenaga Listrik Komputer) Vol. 2 No. 2 e-ISSN : 2621-9700, p-ISSN : 2654-2684

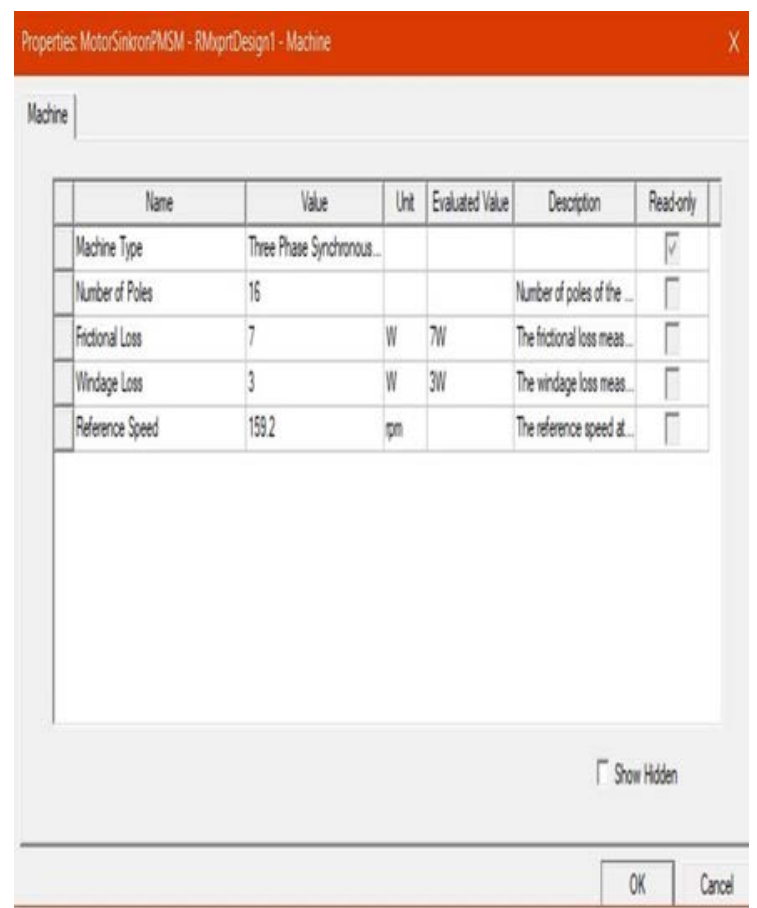

Gambar 2 Memasukan data name plate motor.

\begin{tabular}{|c|c|c|c|c|c|c|}
\hline \multicolumn{6}{|c|}{ 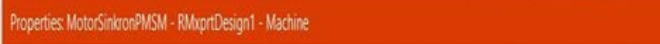 } & $x$ \\
\hline \multicolumn{7}{|l|}{ Stado } \\
\hline Nare & Vale & Uht & Evaluted Vave & Descrition & Peadinty & \\
\hline Qter Dantels & 242 & $m$ & $24 \mathrm{~mm}$ & Ater darter of the s. & $\Gamma$ & \\
\hline me Dreter & 170 & $m$ & $17 \mathrm{~mm}$ & me daretere of the s. & $\Gamma$ & \\
\hline lengh & 250 & $\mathrm{~m}$ & $250 \mathrm{~m}$ & Lengh d the statr cove & $\Gamma$ & \\
\hline Troding frado & 095 & & & Sordingfodad it thes. & $\Gamma$ & \\
\hline Seet Tipe & noded & & & Seed lype d the stalo... & $\Gamma$ & \\
\hline Ninber d Sots & 600 & & & Ninber of setsed thes. & 「 & \\
\hline Sed Tipe & 1 & & & Soltpes d the stace. & $\Gamma$ & \\
\hline Larintion Se. & & & & Nurber dil arinations. & $\Gamma$ & \\
\hline Press Boord T. & & $m$ & & Magetcic pees boadt. & $\Gamma$ & \\
\hline Sken With & 2 & & 2 & Sien withneasuedi. & $\Gamma$ & \\
\hline & & & & $\Gamma$ Shon & whdon & \\
\hline & & & & 0 & OK & Cancel \\
\hline
\end{tabular}

Gambar 3 Memasukan data stator.

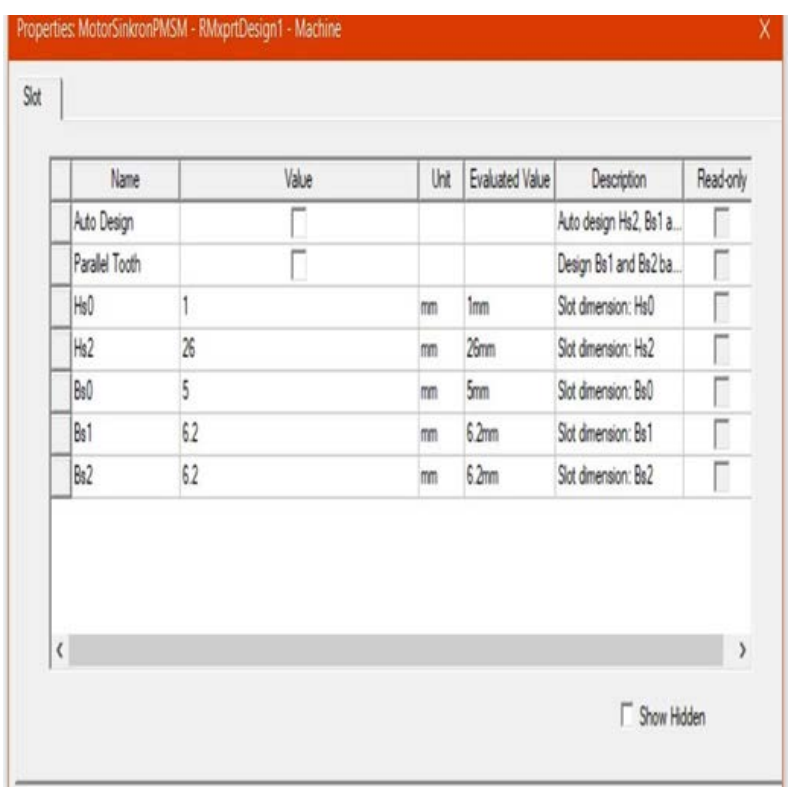

Gambar 4 Memasukan data slot stator.

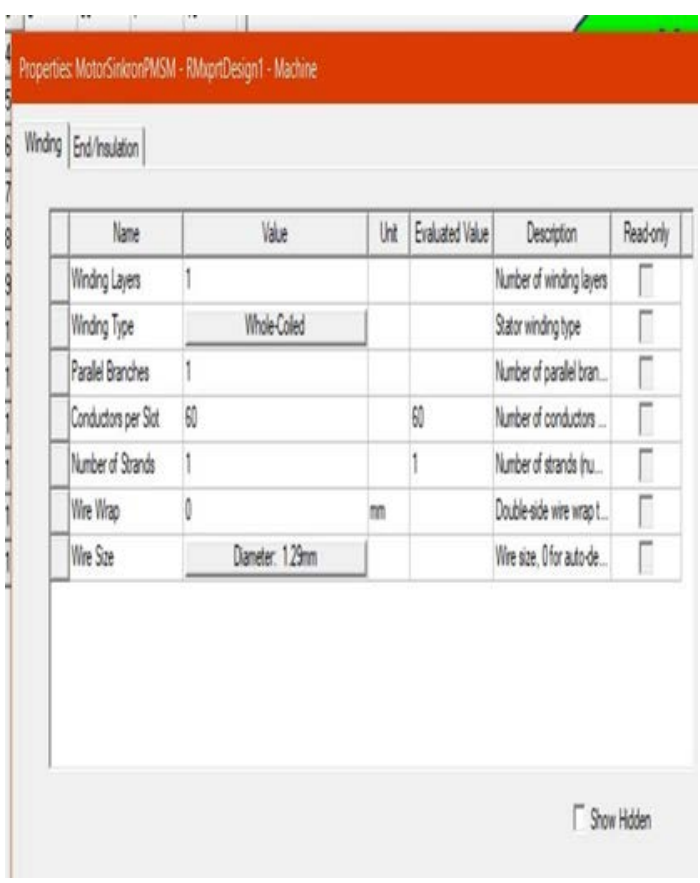

Gambar 5 Memasukan data stator winding. 
RESISTOR (Elektronika Kendali Telekomunikasi Tenaga Listrik Komputer) Vol. 2 No. 2 e-ISSN : 2621-9700, p-ISSN : 2654-2684

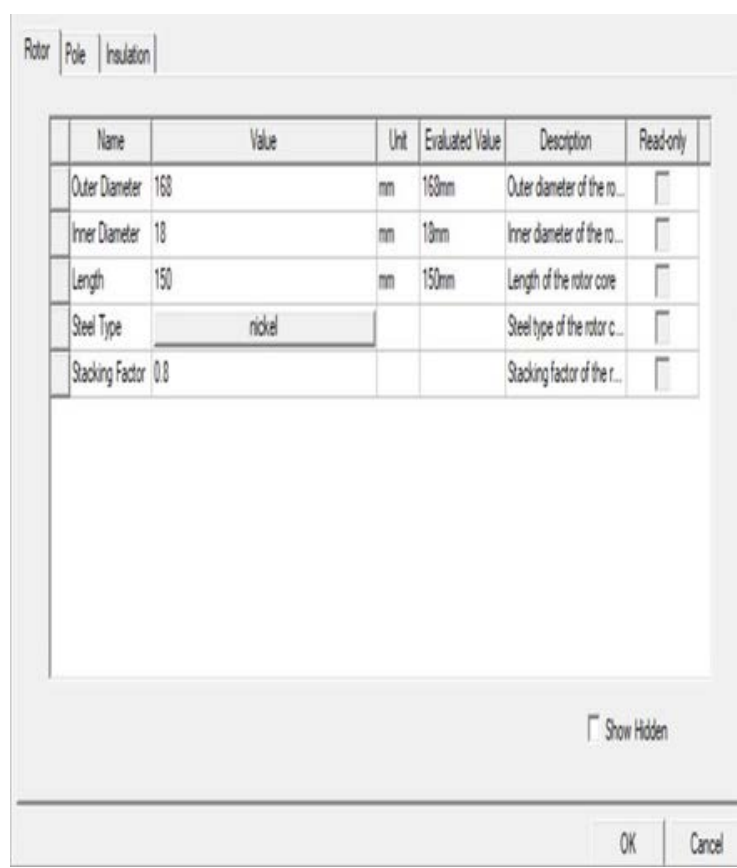

Gambar 6 Memasukan data rotor.

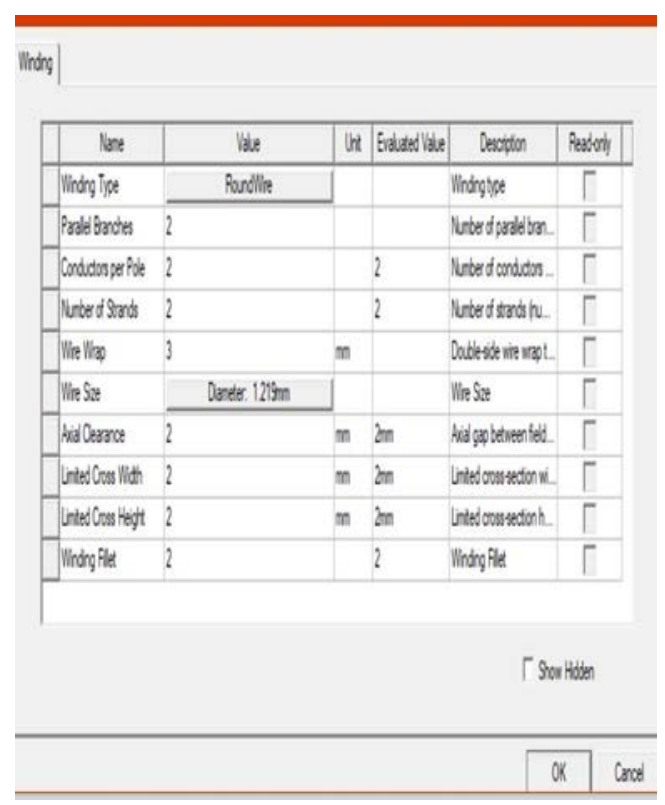

Gambar 7 Memasukan data rotor winding.

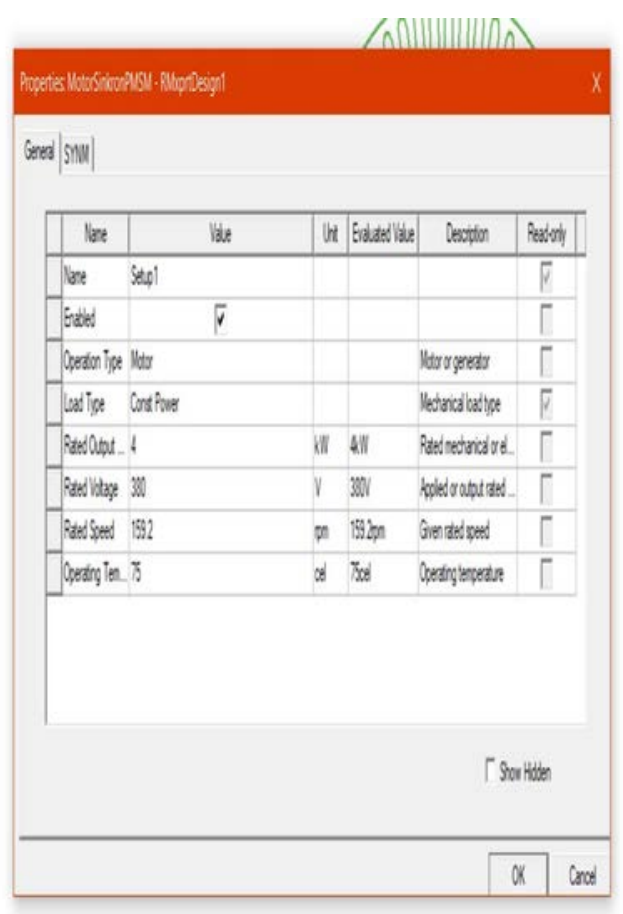

Gambar 8 Analysis setup.
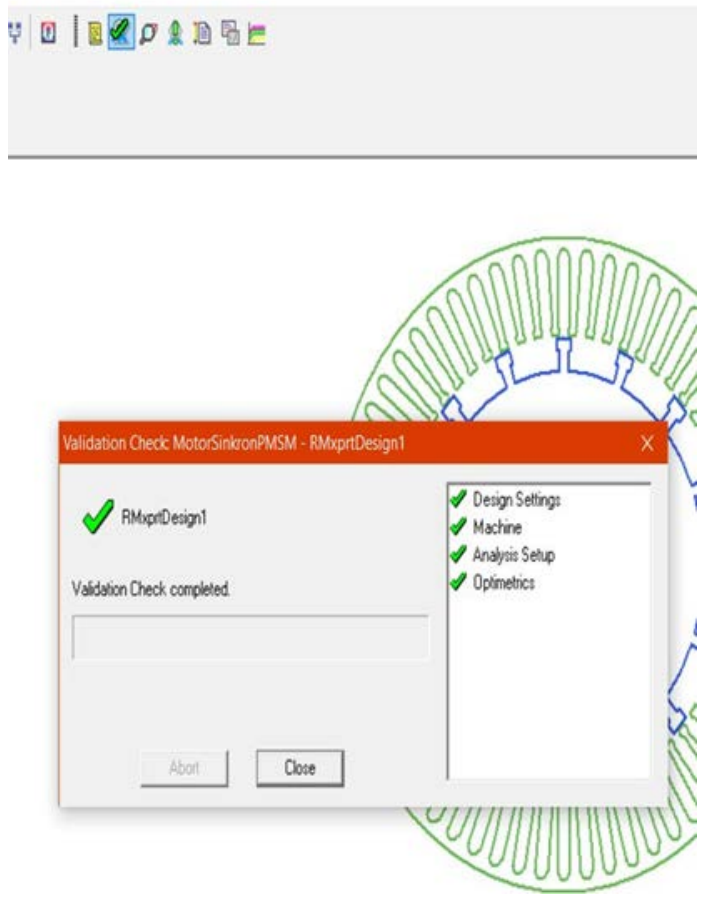

Gambar 9 Validasi design.

3 HASIL DAN PEMBAHASAN 
RESISTOR (Elektronika Kendali Telekomunikasi Tenaga Listrik Komputer) Vol. 2 No. 2 e-ISSN : 2621-9700, p-ISSN : 2654-2684

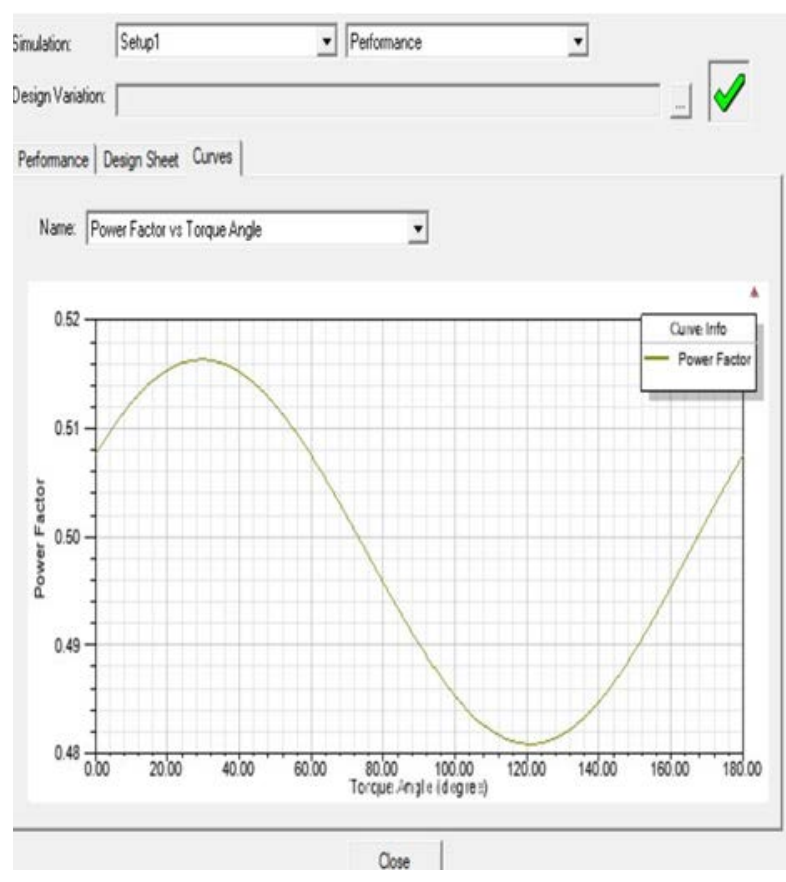

Gambar 10 Power factor vs torque angle.

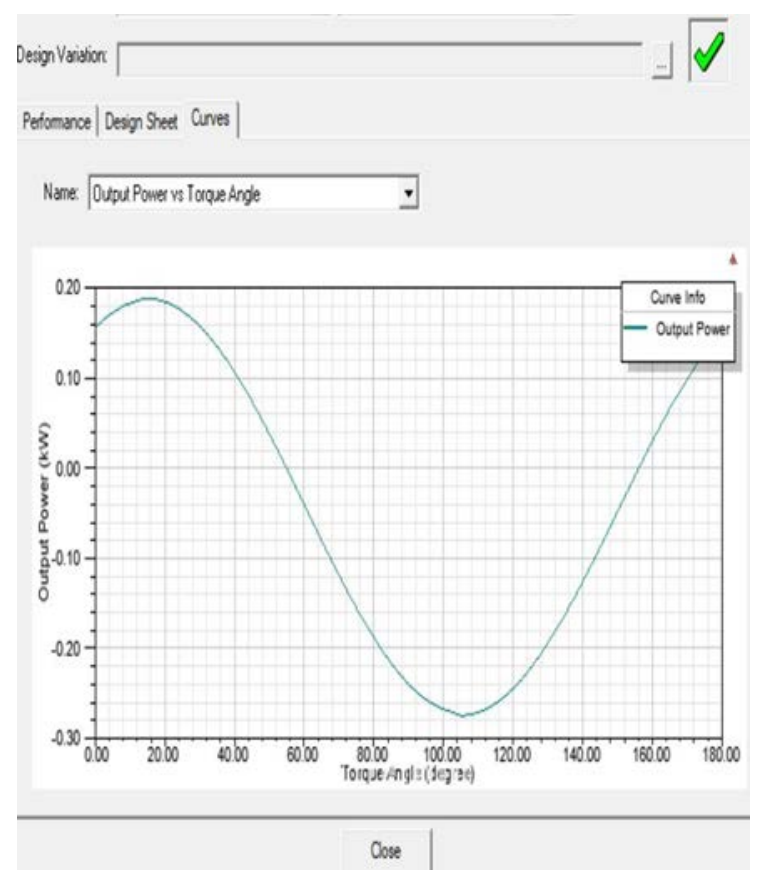

Gambar 11 Output power vs torque angle.

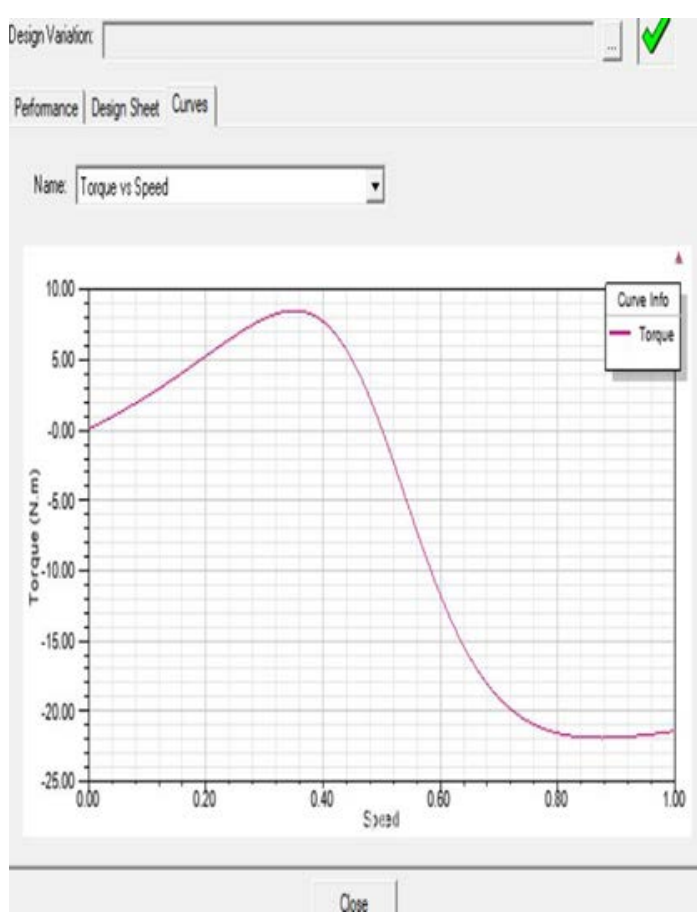

Gambar 12 Torque vs speed.

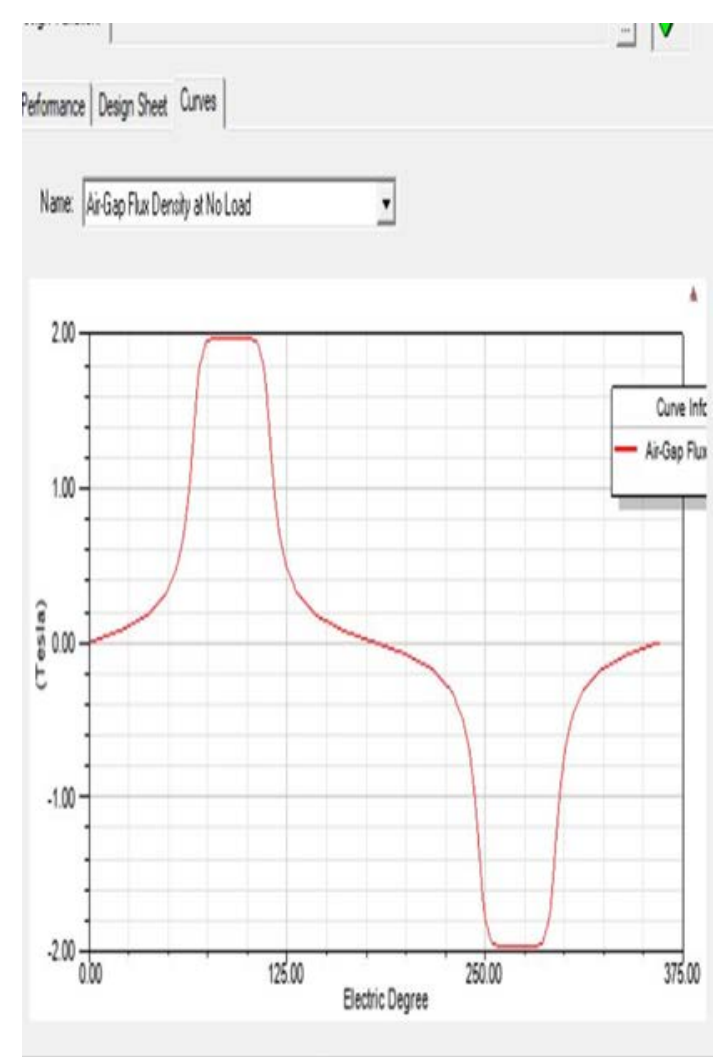

Gambar 13 Air gap flux density no load. 
RESISTOR (Elektronika Kendali Telekomunikasi Tenaga Listrik Komputer) Vol. 2 No. 2 e-ISSN : 2621-9700, p-ISSN : 2654-2684

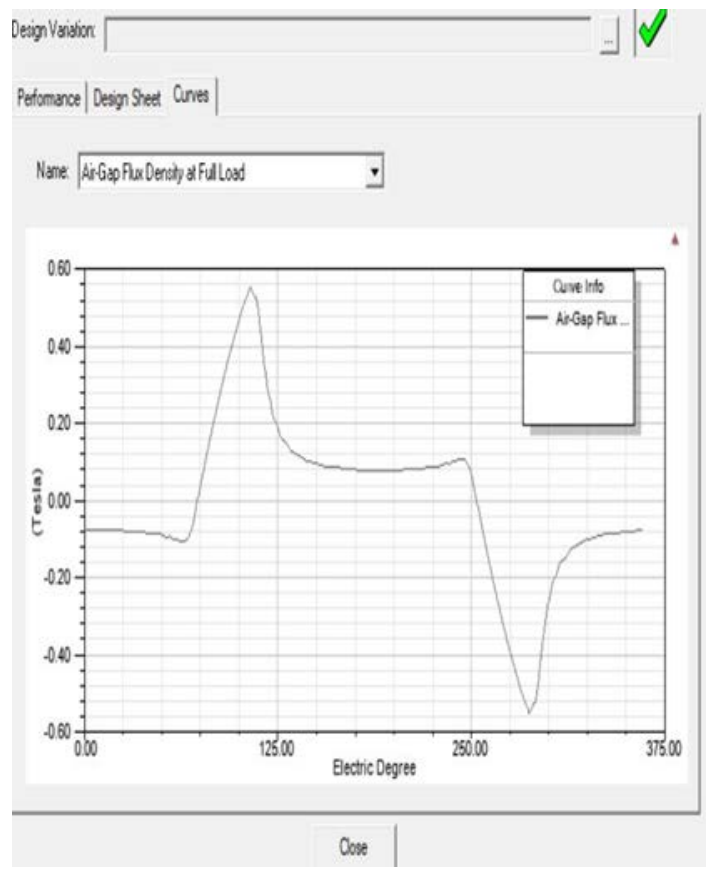

Gambar 14 Air gap flux density full load.

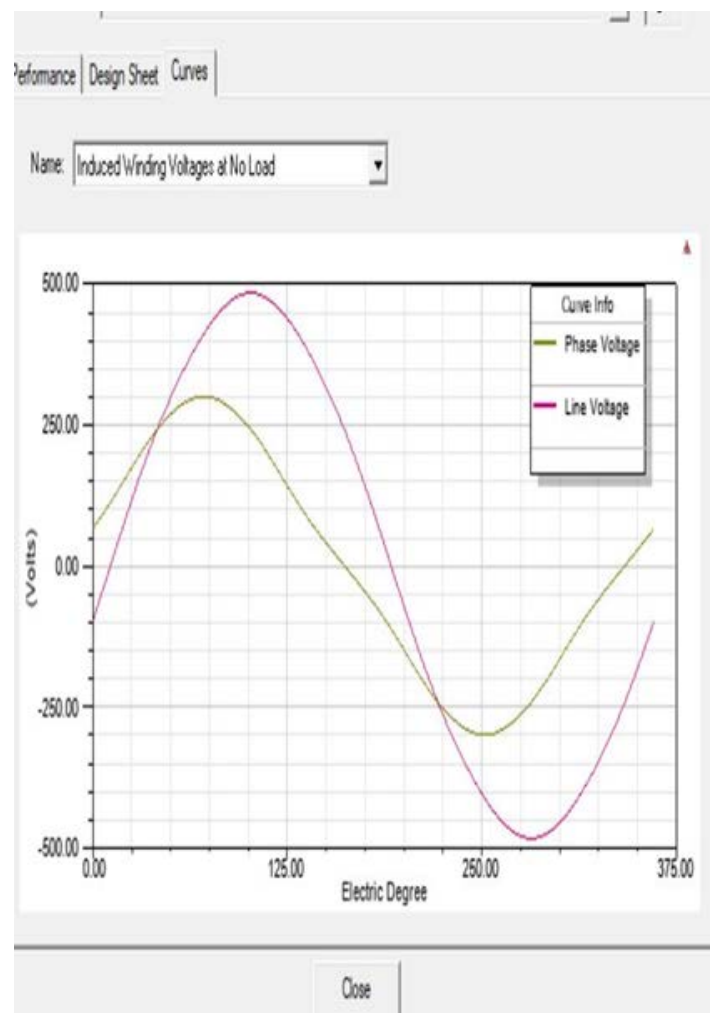

Gambar 15 Induced winding voltage at no load.

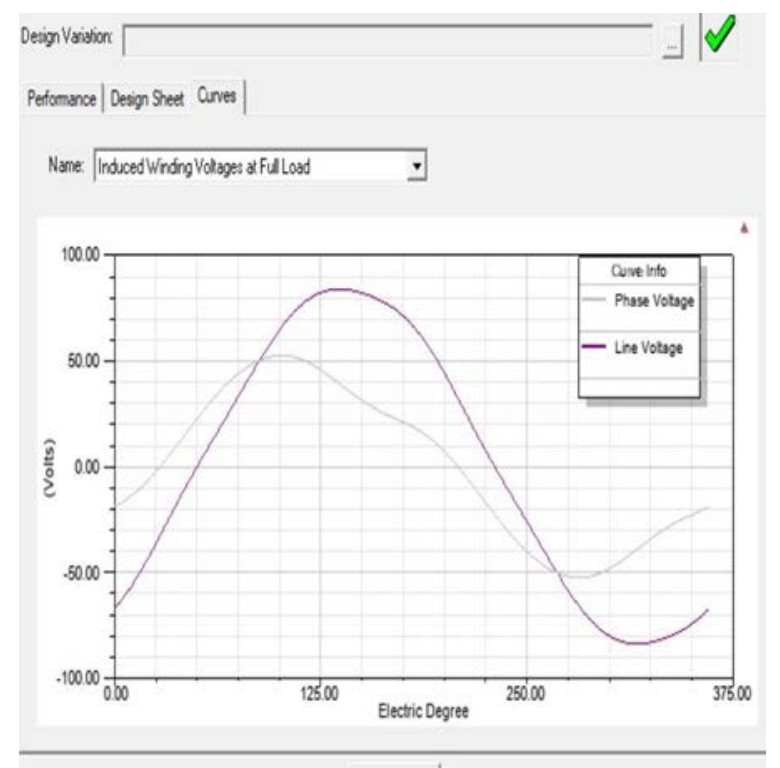

Gambar 16 Induced winding voltage at full load.

\section{KESIMPULAN}

Dari perancangan permanent magnet motor sinkron pada Penelitian ini, maka dapat disimpulkan bahwa efisiensi dapat di poleh dengan mendesain ulang bagian rotor dan stator, kepadatan torsi dapat di kurangi dengan permanent magnet motor sinkron, kekurangan data 2 variabel material berdampak , hasil simulasi kurang maksimal dan mendekati kenyataan.

\section{DAFTAR PUSTAKA}

[1] J. Pyrhonen, T. Jokinen, and V. Hrabovcova, Design of rotating electrical machines. John Wiley \& Sons, 2013.

[2] H. Yetiş, H. Boztepeli, Y. Yaşa, and E. Meșe, "Comparative design of direct drive PM synchronous motors in gearless elevator systems," in 2013 3rd International Conference on Electric Power and Energy Conversion Systems, 2013, pp. 1-5.

[3] G. Wang et al., "Weight-transducerless starting torque compensation of gearless permanent-magnet traction machine for directdrive elevators," IEEE Transactions on Industrial Electronics, vol. 61, no. 9, pp. 4594-4604, 2013.

[4] O. Mansouri-Toudert, H. Zeroug, F. Auger, and A. Chibah, "Improved rotor position estimation of salient-pole PMSM using high frequency carrier signal injection,” in 2013 IEEE International Conference on Mechatronics (ICM), 2013, pp. 761-767. 
RESISTOR (Elektronika Kendali Telekomunikasi Tenaga Listrik Komputer) Vol. 2 No. 2 e-ISSN : 2621-9700, p-ISSN : 2654-2684

[5] D. C. Hanselman, Brushless permanent magnet motor design. The Writers' Collective, 2003.

[6] S. Atiq, T. A. Lipo, and B.-I. Kwon, "Wide speed range operation of non-salient PM machines," IEEE Transactions on Energy Conversion, vol. 31, no. 3, pp. 1179-1191, 2016.

[7] A. Castagnini, P. S. Termini, G. Secondo, and N. Bianchi, "Replacing SPM by PMAREL machines in low-speed high-torque applications," in 2016 IEEE Energy Conversion Congress and Exposition (ECCE), 2016, pp. 1-8.

[8] J. F. Gieras, Permanent magnet motor technology: design and applications. CRC press, 2009.

[9] S. Cicalé, L. Albini, F. Parasiliti, and M. Villani, "Design of a permanent magnet synchronous motor with grain oriented electrical steel for direct-drive elevators," in 2012 XXth International Conference on Electrical Machines, 2012, pp. 1256-1263.

[10] R. L. Ficheux, F. Caricchi, F. Crescimbini, and O. Honorati, "Axial-flux permanentmagnet motor for direct-drive elevator systems without machine room," IEEE Transactions on Industry Applications, vol. 37, no. 6, pp. 1693-1701, 2001.

[11] F. Fadliondi, H. Isyanto, and B. Budiyanto, "Bypass Diodes for Improving Solar Panel Performance," International Journal of Electrical and Computer Engineering, vol. 8, no. 5, p. 2703, 2018.

[12] M. H. Widianto, “Alat Pengatur Suhu Otomatis pada Ruangan Produksi Textile Spining Berbasis Mikrokontroler Atmega32 di PT. San Star Manunggal,” RESISTOR (elektRonika kEndali telekomunikaSI tenaga liSTrik kOmputeR), vol. 2, no. 1, pp. 51-58, 2019.

[13] D. Almanda and D. Bhaskara, "Studi Pemilihan Sistem Pendingin pada Panel Surya Menggunakan Water Cooler, Air Mineral dan Air Laut,” RESISTOR (elektRonika kEndali telekomunikaSI tenaga liSTrik kOmputeR), vol. 1, no. 2, pp. 43-52, 2018.

[14] M. H. Widianto, "Pengaplikasian Sensor Hujan dan LDR untuk Lampu Mobil Otomatis Berbasis Arduino Uno,” RESISTOR
(elektRonika kEndali telekomunikaSI tenaga liSTrik kOmputeR), vol. 1, no. 2, 2018.

[15] F. Fadliondi and B. Budiyanto, "Transistor Efek Medan Berbasis Semikonduktor Organik Pentacene untuk Sensor Kelembaban,” Jurnal Nasional Teknik Elektro dan Teknologi Informasi, vol. 6, no. 2, pp. 204-209, 2017.

[16] H. Isyanto and M. Syahrullah, "Perancangan Security Home (Keamanan pada Rumah) Menggunakan Mikrokontroller Berbasis SMS (Short Message Service)," RESISTOR (elektRonika kEndali telekomunikaSI tenaga liSTrik kOmputeR), vol. 1, no. 2, pp. 85-96, 2018.

[17] E. B. Prasetya, “Aplikasi Manajemen Proyek Konstruksi dengan Metode Critical Path dan Earned Value Management,” RESISTOR (elektRonika kEndali telekomunikaSI tenaga liSTrik kOmputeR), vol. 1, no. 2, pp. 53-68, 2018.

[18] F. Fadliondi, M. Kunta Biddinika, and S. I. Omi, "The Humidity Dependence of Pentacene Organic Metal-OxideSemiconductor Field-Effect Transistor.," Telkomnika, vol. 15, no. 2, 2017.

[19] H. Muchtar and R. Sumanjaya, "Control Switch Otomatis pada Tegangan Energi Alternatif dan Tegangan Sumber PLN Menggunakan Raspberry Pi," RESISTOR (elektRonika kEndali telekomunikaSI tenaga liSTrik kOmputeR), vol. 1, no. 2, 2018.

[20] F. Fadliondi, H. Isyanto, and P. Gagani, "Pengaruh Ketebalan Lapisan Isolator Sio2 terhadap Mobilitas Lubang dari Transistor Efek Medan Organik Pentacene,” Prosiding Semnastek, 2016.

[21] L. Halim and C. F. Naa, "Desain Sistem Pendayaan Energi Listrik pada Rumah Kaca Pintar dengan Menggunakan Pembangkit Listrik Tenaga Surya,” RESISTOR (elektRonika kEndali telekomunikaSI tenaga liSTrik kOmputeR), vol. 2, no. 1, pp. 43-50, 2019.

[22] B. Budiyanto and F. Fadliondi, "The Improvement of Solar Cell Output Power Using Cooling and Reflection from Mirror," International Journal of Power Electronics and Drive Systems, vol. 8, no. 3, p. 1320, 2017.

[23] R. Samsinar and W. Wiyono, "Studi Keandalan Rekonfigurasi Jaringan Program Zero Down Time (Zdt) di Kawasan Sudirman 
RESISTOR (Elektronika Kendali Telekomunikasi Tenaga Listrik Komputer) Vol. 2 No. 2 e-ISSN : 2621-9700, p-ISSN : 2654-2684

Central Business Distric (Scbd) Menggunakan Software ETAP 12.6,” RESISTOR (elektRonika kEndali telekomunikaSI tenaga liSTrik kOmputeR), vol. 2, no. 1, pp. 65-72, 2019.

[24] F. Fadliondi, B. Budiyanto, and H. Isyanto, "SIMULASI KARAKTERISTIK LISTRIK DARI SEL SURYA YANG TERHUBUNG SECARA PARALEL DAN PENGUJIANNYA SECARA EKSPERIMEN,” Prosiding Semnastek, 2018.

[25] F. Fadliondi, N. Hasanah, and A. Asriyadi, "Simulasi dan Pembuatan Rangkaian Penyearah Gelombang Penuh dengan Trafo Center Tapped dengan Memakai Perangkat Lunak LT SPICE,” RESISTOR (elektRonika kEndali telekomunikaSI tenaga liSTrik kOmputeR), vol. 2, no. 1, pp. 23-28, 2019.

[26] F. Fadliondi and A. Asriyadi, "Eksperimen dan Simulasi Rangkaian Band Pass Filter (BPF) dengan Resistor dan Kapasitor," RESISTOR (elektRonika kEndali telekomunikaSI tenaga liSTrik kOmputeR), vol. 1, no. 2, pp. 69-78, 2018.

[27] S. Sriyono and B. Budiyanto, "Studi Penggunaan DC Nanogrid dengan Sumber Photovoltaic pada Beban Bertegangan dibawah Dua Puluh Empat Volt,” RESISTOR (elektRonika kEndali telekomunikaSI tenaga liSTrik kOmputeR), vol. 2, no. 1, pp. 1-6, 2019.

[28] H. Isyanto, A. Solikhin, and W. Ibrahim, "Perancangan dan Implementasi Security System pada Sepeda Motor Menggunakan RFID Sensor Berbasis Raspberry Pi," RESISTOR (elektRonika kEndali telekomunikaSI tenaga liSTrik kOmputeR), vol. 2, no. 1, pp. 29-38, 2019.

[29] D. Almanda and B. Kusuma, "Audit Energi Listrik Pabrik,” RESISTOR (elektRonika kEndali telekomunikaSI tenaga liSTrik kOmputeR), vol. 1, no. 1, 2018.

[30] D. Almanda and N. Majid, "Studi Analisa Penyebab Kerusakan Kapasitor Bank Sub Station Welding di PT. Astra Daihatsu Motor," RESISTOR (elektRonika kEndali telekomunikaSI tenaga liSTrik kOmputeR), vol. 2, no. 1, pp. 7-14, 2019.

[31] H. Isyanto, F. Fadliondi, and B. Budiyanto, "STUDI SIMULASI DAN EKSPERIMEN PADA KARAKTERISTIK LISTRIK SEL
SURYA YANG TERHUBUNG SECARA SERI,” Prosiding Semnastek, 2018.

[32] R. Samsinar, N. Purnomo, and D. Almanda, "Studi Kelayakan Core Iron Stator Dengan Metode Loop/ELCID Test,” RESISTOR (elektRonika kEndali telekomunikaSI tenaga liSTrik kOmputeR), vol. 1, no. 2, pp. 103-116, 2018.

[33] H. Isyanto and D. Arsito, "Sistem Pengaman Rumah dan Peringatan Dini Kebakaran Berbasis SMS dengan Menggunakan Raspberry Pi,” RESISTOR (elektRonika kEndali telekomunikaSI tenaga liSTrik kOmputeR), vol. 1, no. 1, pp. 13-24, 2018.

[34] H. Muchtar and R. Apriadi, "Implementasi Pengenalan Wajah Pada Sistem Penguncian Rumah Dengan Metode Template Matching Menggunakan Open Source Computer Vision Library (Opencv)," RESISTOR (elektRonika kEndali telekomunikaSI tenaga liSTrik kOmputeR), vol. 2, no. 1, pp. 39-42, 2019. 